\title{
Psychotherapy in The Netherlands after the Second World War
}

\author{
GIEL J M HUTSCHEMAEKERS and HARRY OOSTERHUIS*
}

\section{Introduction}

The early history of psychotherapy in the Netherlands hardly differs from that of the surrounding countries. Somewhat later than in France and Germany, psychotherapy appeared during the last decades of the nineteenth century, ${ }^{1}$ with general practitioners who started to treat their patients (mainly for all kinds of somatic complaints) by psychological means. ${ }^{2}$ In the early decades of the twentieth century, psychotherapy was narrowed down to mainly psychoanalytic treatment. The patient population consisted of a small élite group of people who belonged to the upper social classes. The practice of psychotherapy was restricted to some "enlightened" psychoanalysts. ${ }^{3}$

However, the more recent history of Dutch psychotherapy is much more unusual. The increase in ambulatory mental health care services as well as psychotherapy was higher than elsewhere in Europe. ${ }^{4}$ Psychotherapy grew so fast that by the 1980 s it was considered the best form of treatment in ambulatory mental health care. ${ }^{5}$ Even more exceptional was the establishment of a separate profession for psychotherapists, so that as well as being registered as a psychiatrist, general doctor, psychologist or even social worker, it was possible to be registered as a psychotherapist. This phenomenon has been characterized as "le phénomène hollandais", 6

This article deals with this recent history of psychotherapy in the Netherlands. The main focus is on the developing institutions as well as on the establishment of the psychotherapeutic profession. The first section describes the period between the foundation of the first

\footnotetext{
* Professor Giel Hutschemaekers, GRIP Gelderse Roos, Wolfheze 2, 6874 BE Wolfheze, The Netherlands; g.hutschemaekers@degelderseroos.nl; Harry Oosterhuis, PhD, Department of History, University of Maastricht, PO Box 616, 6200 MD Maastricht, The Netherlands;

Harry.Oosterhuis@HISTORY.unimaas.nl

${ }^{1}$ Christien Brinkgreve, Psychoanalyse in Nederland; een vestingsstrijd, Amsterdam, Synopsis, 1984, pp. 31-53.

${ }^{2}$ Pierre Dubois, les psychonévroses et leur traitement moral, Paris, Masson, 1904, 3rd ed., 1909, pp. 14-28, 112-32.

${ }^{3}$ Henry Ellenberger, The discovery of the unconscious: the history and evolution of dynamic psychiatry, New York, Basic Books, 1970, pp. 749-885.

${ }^{4}$ Harry Oosterhuis, 'Insanity and other discomforts: a century of extramural psychiatry and mental
}

health care', paper presented at the International Workshop 'Cultures of Psychiatry and Mental Health Care in the Twentieth Century: Comparisons and Approaches', Trimbos-instituut Utrecht, University of Amsterdam, University of Maastricht, Amsterdam, 18-20 September 2003.

${ }^{5}$ Paul Schnabel, 'Psychotherapie tussen de jaren zeventig en negentig', in J A M Winnubst, P Schnabel, $\mathrm{J}$ van den Bout and M J M van Son (eds), De metamorfose van de klinische psychologie. Nieuwe ontwikkelingen in de klinische en gezondheidspsychologie, Assen, Maastricht, Van Gorcum, 1991, pp. 23-38, on p. 24.

${ }^{6}$ Piet Jongerius, 'Le phénomène hollandais, een geschiedenis van het psychotherapeutisch veld', in J Vijselaar (ed.), Ambulant in zicht. Verslag van het symposium op 17 januari 1986 te Zeist, Utrecht, Nederlands centrum Geestelijke volksgezondheid (NcGv), 1987, pp. 120-36. 


\section{Giel J M Hutschemaekers and Harry Oosterhuis}

psychotherapeutic institute in Amsterdam in 1940 and the emergence of the regional ambulatory centres for mental health care (RIAGG) in 1982. In this period the number of patients benefiting from psychotherapy grew rapidly; shifts in the attitude of society towards psychology in general and the individualization of people supported the emancipation of the patient. At the same time, as will be shown in the second section, the history of psychotherapy partly covers the process of the professionalization of the psychotherapist. In 1930 only a few psychoanalysts regarded themselves as psychotherapists, whereas in 2000 almost 5,000 psychotherapists were officially registered as such. The formal and multidisciplinary character of the profession is typically Dutch: it has a legal status and, apart from general doctors and psychiatrists, the vast majority of psychotherapists are also psychologists. In the third section, we will briefly describe recent developments. Firstly, the effects of the rise in popularity of biological psychiatry are depicted and secondly, the efforts being made to dismantle the profession. We will argue that these events could reveal another transformation in the way in which mental health problems are considered.

\section{The Rise of Psychotherapy: From IMP to RIAGG}

Modern psychotherapy in the Netherlands first appeared at the end of the nineteenth century. Frederik van Eeden and Albert van Renterghem were two general practitioners who started to use "those forms of medical treatment in which the disease is treated by psychological means through the use of psychic functions", 7 thus becoming the first psychotherapists in the Netherlands. Their private practice was the first institution for psychotherapy. In their psychotherapy they combined the agogic and the dynamic traditions. As general practitioners they used their authority and gave advice and instruction to their patients on how to handle their complaints. ${ }^{8}$ As disciples of Liébeault they also used hypnosis and cathartic methods. With these methods they treated patients from various social classes who had somatic as well as psychosomatic complaints.

During the first decades of the twentieth century, psychotherapy was mainly limited to psychoanalytic treatment for upper-class patients. The practice of psychotherapy was restricted to some psychiatrists in private practice who were members of the Psychoanalytic Society. The reaction to this restriction occurred in the 1930s. A group of psychiatrists tried to adapt psychotherapeutic treatment so that it could be offered to a larger public. The establishment of the Nederlandse Vereniging voor Psychotherapie (NVP, Dutch Society of Psychotherapy) in 1930 was part of this movement, as was the foundation of the first Institute for Medical Psychotherapy (IMP) in 1940.

\section{The Institute for Medical Psychotherapy}

On 15 May 1940, five days after the Germans had invaded the Netherlands, the IMP officially opened its doors in Amsterdam. The Institute was dedicated to offering psychotherapeutic help to destitute war victims. The foundation of the IMP formed part of the

\footnotetext{
${ }^{7}$ Frederik van Eeden, 'Psychotherapie' (literatuuroverzicht), $N T v G, 1890,26$ : 441 . For van Eeden the psychic function par excellence was the
}

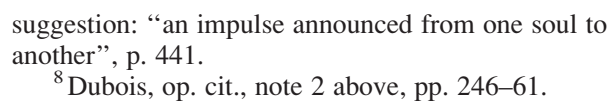




\section{Psychotherapy in The Netherlands after the Second World War}

broader mental health movement. ${ }^{9}$ This movement aimed to improve the mental health of society as a whole by ameliorating mental health care outside the clinic. The IMP was set up to help those adult patients who had psychogenic complaints but did not suffer from psychiatric disorders. The IMP had two tasks to perform. Firstly, it had a preventive function: the protection of mental health through correct and timely diagnosis. Secondly, the IMP had a treatment function as an outpatient clinic for "patients of limited means" who were suffering from a disorder caused by war conditions. The target group consisted of ordinary unstable people who, under normal conditions would have kept their balance. ${ }^{10}$ In the first year, ninety-four patients were admitted to the IMP and seventy-five received psychotherapeutic treatment with an average of seven sessions. ${ }^{11}$

In its first years the IMP suffered from two major problems: financial difficulties and the lack of agreement on the need for such treatment. From the onset, the new Institute lacked economic stability. The first financier was the government fund for air defence, a responsibility that was later taken over by the city of Amsterdam. It was only after 1965 that another public system of funding was achieved. In the first few years the funds were quite modest. According to Professor K H Bouman, one of the founders, these limited resources had direct consequences for both staff and patients. Staff had to agree on salaries that were lower than the average fees in psychiatric clinics and private practices. The selection of patients was affected because only those who would benefit from a short intervention were admitted. The second problem concerning lack of agreement on the need for such treatment was less concrete but as persistent as the first. From a traditional psychoanalytic viewpoint, the IMP was selecting the wrong patient group and using the wrong methods of treatment; short interventions were considered to be of too limited use. In contrast, psychiatrists working with acute psychiatric problems believed the opposite: the IMP patients did not need any psychiatric help at all. ${ }^{12}$ This attitude seemed to be validated by the reactions of people to the war: shell-shock symptoms remained rare, demonstrating once again "the down-to-earthness" of the Dutch people. ${ }^{13}$

Immediately following the war, in 1946, the question whether the IMP offered the right care to the right people led to an internal conflict between the orthodox and more liberal psychoanalytic therapists. The first group, who did not believe in short interventions, left the IMP and created their own psychoanalytic institute in Amsterdam (PAI). The second group, who did believe in short interventions, stayed at the IMP. However, at the same time, many of the psychiatrists and other mental health care workers who believed in short interventions

\footnotetext{
${ }^{9}$ Christien Brinkgreve, Jan Onland, and Abraham de Swaan, Sociologie van de psychotherapie 1. De opkomst van het psychotherapeutisch bedrijf, Utrecht, Antwerp, Het Spectrum, 1979, pp. 34-48. See also Leonie de Goei, De psychohygiënisten, Nijmegen, SUN, 2001. K H Bouman, one of the founders of the IMP, was also a prominent member of the movement, on pp. 151-4.

${ }^{10}$ Brinkgreve, et al., op. cit., note 9 above, p. 36.

${ }^{11}$ Ibid., p. 37.

${ }^{12}$ The most fanciful anecdote is reported by De Ridder and Van Lieshout: unofficially the IMP opened its doors just before the German invasion on
}

10 May . The first patient file (unfortunately destroyed) was that of a man who presented himself in the first week of May 1940. He was depressed and anxious, and terrified by the idea that the Germans would invade. In the patient file it was noted: "patient is suffering from paranoia; he is thinking the Germans will come", cited in Denise de Ridder, Peter van Lieshout, Symptomen van de tijd. De dossiers van het Amsterdamse instituut voor medische psychotherapie. IMP 1968-1977, Nijmegen, SUN, 1991, p. 31.

${ }_{13}$ Curatorium IMP 21-11-1940, in Brinkgreve, et al., op. cit. note 9 above, p. 40. 


\section{Giel J M Hutschemaekers and Harry Oosterhuis}

did not accept the IMP's monopoly; they preferred institutes with direct links to various religions, such as the new agencies focusing on "life and family problems" (the Bureaux voor Levens- en Gezinsmoeilijkheden, [LGV]). These LGVs did not offer psychotherapy as such but made use of all kinds of new psychosocial methods; treatment was given by general practitioners, psychologists and social workers. The majority of psychiatrists working in the LGV had only a consultative function. At that time the distinction between this psychosocial treatment and psychotherapy was still evident, simply because psychotherapy was a medical intervention which could only be performed by psychiatrists. The LGV, which employed mostly non-medical mental health professionals, had a much more successful start than the IMP. In 1936 the first LGV opened in Rotterdam and in 1942 a second LGV was established in The Hague. By 1950 there were eleven Catholic, four Protestant and four neutral agencies, whereas in 1962 there were twenty-seven Catholic, sixteen Protestant, four humanistic, three neutral and one Jewish facilities. ${ }^{14}$

The spread of "neutral" psychotherapy took much more time. The second IMP was founded in Utrecht in 1953. More than ten years later institutes in Leeuwarden, Groningen and The Hague followed. From the late 1960s the number of IMPs rose quickly: thirteen in 1976, seventeen in 1980 and twenty-four in 1981. ${ }^{15}$ Meanwhile, in 1965, the M for medical in the name IMP had developed a new meaning: multidisciplinary.

\section{A Paradigm Shift}

The growth of the IMPs in the 1960s and 1970s was probably a symptom of a more profound shift in mental health care and society in general. Several transformations in mental health care took place at that time. Besides the expansion of the IMPs, psychotherapy gained influence in other settings. In outpatient clinics such as the above-mentioned LGV, all kinds of new psychotherapeutic methods were introduced, especially partner and relationship therapy and, somewhat later, family therapy. ${ }^{16}$ In the Medisch Opvoedkundig Bureau (MOB, the Child Guidance Clinic) for children at risk and their parents, the psychotherapeutic approach had become dominant much earlier, in the $1930 \mathrm{~s} .{ }^{17}$ In addition, new psychotherapeutic methods were introduced in the 1960s in the Social-Psychiatric Services and the outpatient clinics for chronic psychiatric patients that resulted in social psychiatric nurses beginning to consider themselves as therapists. ${ }^{18}$

The psychotherapeutic approach also gained more influence in the psychiatric hospitals. As early as the 1950s, the principal diagnostic framework was the combination of psychoanalytic theory with the phenomenological approach. However, for most patients,

\footnotetext{
${ }^{14}$ Nationale Federatie voor de Geestelijke Volksgezondheid, Gids voor de Geestelijke Volksgezondheid in Nederland, Amsterdam, NFGV, 1950, pp. 65, 68-9; idem, Gids voor de Geestelijke Gezondheidszorg in Nederland, Amsterdam, NFGV, 1962, pp. 240-6.

${ }^{15}$ Giel Hutschemaekers, Neurosen in Nederland: vijfentachtig jaar psychisch en maatschappelijk onbehagen, Nijmegen, SUN, 1990, p. 46.

${ }^{16} \mathrm{~L}$ Geelen-Vos, 'Van bureau voor huwelijksaangelegenheden naar Riagg-volwassenenzorg?', in J Vijselaar (ed.),
}

\author{
Ambulant in zicht. Geschiedenis van de ambulante \\ geestelijke gezondheidszorg in Nederland, Utrecht, \\ NcGv, 1987, pp. 102-19. \\ ${ }^{17}$ Anneke van der Wurff, " "Niet zoo maar een \\ meening, doch een welbewust gegeven psychiatrisch \\ advies" Medische Opvoedkundige Bureaus in \\ Nederland, 1928-1980', in Vijselaar (ed.), op. cit., \\ note 16 above, pp. 83-100. \\ ${ }^{18}$ Freek Frets, 'Van verheffing tot behandeling: \\ de ontwikkeling van de praktische sociale \\ psychiatrie', in Vijselaar (ed.), op. cit., note \\ 16 above, pp. 56-82.
}




\section{Psychotherapy in The Netherlands after the Second World War}

psychotherapeutic treatment was considered inadequate. ${ }^{19}$ At the same time, the first signs of a more profound shift appeared. First, the change of the name "asylum" to "mental hospital"; second, the introduction of non-verbal interventions (art therapy and movement therapy) and third, the emergence of the multidisciplinary team. These transformations constituted the prologue to the anti-psychiatric movement that occurred in the late $1960 \mathrm{~s} .^{20}$

The most significant sign that times were changing was the introduction of the psychotherapeutic community. As early as 1946 the first therapeutic community was built in Austerlitz near Zeist in Utrecht as a military hospital for soldiers suffering from neurosis. This hospital offered treatment to ex-soldiers with shell shock. Later it opened its doors to all kinds of soldiers with neurosis. This hospital worked on the principles of Maxwell Jones: the interaction among the patients themselves and patients with staff was planned in such a way as to be of therapeutic benefit. ${ }^{21}$ In 1949 a second clinic was opened: Veluweland in Lunteren (nowadays part of the Gelderse Roos in Gelderland). In 1988 the Netherlands counted thirty-one clinics with psychotherapeutic communities. However, total admissions in that year were only $500 .^{22}$ This number was quite modest by comparison with the overall admissions to psychiatric hospitals, which amounted to almost $35,000 .^{23}$ In addition to these psychotherapeutic clinics, day clinics developed psychotherapeutic programmes. In 1962 the first day clinic was started in Wolfheze. In 1986 almost all clinics had one or more day clinics. In that year 6,004 patients were admitted. Psychotherapeutic treatment was offered in half of the clinics.

These changes in mental health care were part of the much broader anti-psychiatric movement. Instead of thinking of psychiatric troubles as a symptom of a more or less biological substratum (medical model), its advocates postulated a much more social origin: patients suffered from an insane social world. They argued that psychiatrists, acting as an extension of the ruling (social) classes, exerted repressive power on their patients in order to keep them silent and powerless. Such was the theory of anti-psychiatric psychiatrists: R D Laing in the UK, Klaus Dörner in Germany and Jan Foudraine in the Netherlands. By using psychotherapeutic methods, they showed how schizophrenics suffered from their mothers (double bind) or from the way psychiatric hospitals were organized (total institutions à la Erving Goffman). This use of psychotherapy was suspect because it was directed at the social adaptation of the patient and not at changing the world around the patient. The antipsychiatry movement, however, used the above theory not only as a method to prove that the patient was strongly influenced by his or her social context, but also as a way of changing both patient and environment. ${ }^{24}$ These changes were also anti-psychiatric in the sense that the traditional hierarchic roles in mental health care were reversed. Instead of the doctor taking on the role of "absolute monarch", the multidisciplinary team held ultimate power.

\footnotetext{
${ }^{19}$ Annemarie Kerkhoven, Beeld van de psychiatrie 1800-1970. Historisch bezit van de psychiatrische ziekenhuizen in Nederland, Zwolle, Waanders, 1996, pp. 233-6.

${ }^{20}$ See Gemma Blok, 'Baas in eigen brein. "Antipsychiatrie" in Nederland, 1965-1985', $\mathrm{PhD}$ thesis, University of Amsterdam, 2004.

${ }^{21}$ Hutschemaekers, op. cit., note 15 above, pp. 39-41.
}

\footnotetext{
${ }^{22}$ Frank Lemmens, Jooske van Busschbach, Denise de Ridder, and Peter van Lieshout, Psychotherapie in de riagg. De stand van zaken in 1988, Utrecht, NcGv, 1988.

${ }^{23}$ Curd Jacobs and Evert Ketting, GGZ in getallen 1989. Kwantitatieve ontwikkelingen in de geestelijke gezondheidszorg, Utrecht, NcGv, 1989, on p. 5.

${ }^{24}$ See David Ingleby, Critical psychiatry: the politics of mental health, Harmondworth, Penguin, 1981.
} 


\section{Giel J M Hutschemaekers and Harry Oosterhuis}

This is not the place to elaborate on the anti-psychiatric movement or the changes in society that took place during the 1960 s and 1970s ${ }^{25}$ It will suffice to comment on the way that psychic distress was represented in society. Following a period in which societal reform had been placed on the agenda, the 1970s transformed this into the belief that individual human beings can be fundamentally changed. Men and women in the West perceived themselves increasingly as autonomous beings. Through this belief they gained more access to their own emotional states. Suddenly, emotional distress became something that needed to be explored and not repudiated. It was suspected that behind these emotions there lay the existence of a "true self" that needed to be actualized and developed. ${ }^{26}$

With the introduction of the ideology of self-actualization, the taboo on psychotherapy diminished: a person looking for psychotherapy was no longer considered as mentally ill, but as someone who invested in his or her own mental health. According to this view psychotherapy became the royal road to a "true self" that was hiding behind all kinds of traumas or socialization processes. New techniques such as "sensitivity training" were introduced and the client-centred approach of Carl Rogers with its experiential focusing gained great popularity. Therefore, a new form of psychotherapy was developed: psychodynamic theory became popular and was coupled to the humanistic psychology of Abraham Maslov as well as the principles of Gestalt psychology. ${ }^{27}$

The new paradigm meant that treatment possibilities could be created for new types of clients. The first expansion had been achieved by the emergence of the therapeutic community; psychotherapy not only gained a definitive place within the psychiatric hospital but also offered treatment possibilities for certain patients with psychotic and personality disorders. The second extension was (as already noted) the actualization of the self, which was not limited only to those clients with neurotic complaints. In fact, this therapeutic method attracted a lot of "health seekers" who functioned quite well socially but who had problems with finding their place within a (materialistic) society. ${ }^{28}$ Finally, the third extension had to do with the emergence of so-called psychotherapeutic learning techniques. Behavioural therapy showed people how to shape their behaviour and how to overcome neurotic conditions such as phobias, fear of failure, minor depressions, etc. Clients who suffered from these complaints could be called mild neurotics.

However, it was not only the new groups of clients who were responsible for the described changes. Also, clients reported fewer and fewer somatic complaints such as vague nervous conditions, conversion disorders and somatic correlates of anxiety and depression, but more psychic problems such as feelings of depression, inferiority, etc. They also started to use the vocabulary of the professionals themselves such as (lack of ) assertiveness, hyperventilation,

\footnotetext{
${ }^{25}$ See de Goei, op. cit., note 9 above; Jan Willem Duyvendak, De planning van ontplooiing. Wetenschap, politiek en de maakbare samenleving, The Hague, SDU, 1999; and Evelien Tonkens, Het zelfontplooiingsregiem. De actualiteit van Dennendal in de jaren zestig, Amsterdam, Bert Bakker, 1999.

${ }^{26}$ Ruud Abma, 'De patiënt. De opkomst van de therapeutische samenleving', in Jeroen Jansz and Peter van Drunen (eds), Met zachte hand. Opkomst en
}

verbreding van het psychologisch perspectief, Amsterdam, Lemma, 1996, pp. 115-34, on pp. 129-30.

${ }^{27}$ Ruud Abma, 'Back to normal. Opkomst en ondergang van de psy-kritiek', in R Abma, et al., Het verlangen naar openheid. Over de psychologisering van het alledaagse, Amsterdam, de Balie, 1995, pp. 75-83, on p. 79 .

${ }^{28}$ Ibid., p. 80 . 


\section{Psychotherapy in The Netherlands after the Second World War}

etc. ${ }^{29}$ Thus the problems seen and treated in the psychotherapy offices changed dramatically during these years.

\section{The RIAGG: The Regional Institutes for Ambulatory Mental Health Care}

The exact influence of the anti-psychiatric movement is hard to determine. The transformation of mental health care started long before the appearance of anti-psychiatry. ${ }^{30}$ Nevertheless, the RIAGG can be considered as the inheritor of that movement. ${ }^{31}$ At least two central points in the formation of the RIAGG originated with anti-psychiatry: prioritizing ambulatory mental health care instead of psychiatric care in hospitals, and the dominance of the psychotherapeutic tradition over the biomedical model of psychic disorders.

Officially the RIAGG started on 1 January 1982. It brought together the different institutions for ambulatory mental health care in one organizational unit: the MOB (Child Guidance Clinic) the SPD (Social-Psychiatric Services), the LGV (agency for life and family problems) the psycho-geriatric agency (part of the community medical aids), and the IMP. The RIAGG had several functions: social psychiatric aid, psychotherapeutic treatment, consultation and service to primary health care, and prevention. The RIAGG continued to perform all the functions of the former institutions. The new aspect of the RIAGG was the way it was financed by public funds and its organizational structure.

What then was the advantage of this new institution? The formal point was that the RIAGG could guarantee that everyone, regardless of place of residence, had equal rights and access to ambulatory psychiatric help. For that purpose, the Netherlands was divided into fifty-nine regions of 150,000 to 300,000 inhabitants. Each region had its own RIAGG and each RIAGG was organized along roughly the same lines for providing ambulatory mental health care. For many regions this implied not only an increase of mental health care services, especially for psychotherapy, but also a more orderly organizational structure. Instead of an amalgam of institutions belonging to different religious sectors that were sometimes in strong competition with each other, it led to one new structure for ambulatory mental health care. It is, of course, open to discussion to what degree the RIAGG has realized this democratic ideal of equal accessibility. ${ }^{32}$

There was a second reason for setting up the new organization: it was constructed as a counterweight to the conservative psychiatric hospitals. ${ }^{33}$ The National Inspectorate for Mental Health wanted an organization with two foci: a clinical centre and an ambulatory or outpatient centre. The offer of outpatient care independent of the clinic gave patients a choice and they were not dependent on hospitals. ${ }^{34}$ The psychiatric hospitals reluctant acceptance of the RIAGG was probably related to this underlying strategic position of the new institution.

Less evident was the negative reaction of the IMPs to the RIAGG organization. Together with the other RIAGG partners, the IMP feared it would lose its autonomy. However, the

\footnotetext{
${ }^{29}$ Hutschemaekers, op. cit., note 15 above, pp. 240-7.

${ }^{30}$ Blok, op. cit., note 20 above.

${ }^{31}$ See Tom van der Grinten, De vorming van de ambulante geestelijke gezondheidszorg, Baarn, Ambo, 1987, pp. 279-84; Sonja van't Hof, Een ambt hoog en subtiel. Psychiaters over
}

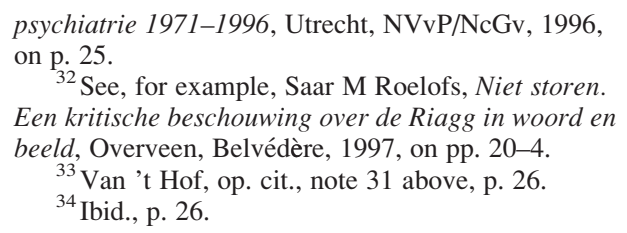




\section{Giel J M Hutschemaekers and Harry Oosterhuis}

opposition put up by the IMP was so fierce that other explanations should be considered. There were financial reasons: psychotherapists were afraid their huge salaries, which were on the same level as those of psychiatrists, would be cut and that they would lose control over the considerable subsidies they received from public funds for training activities for new psychotherapists. Moreover, the IMPs were under the impression that the newlyformed RIAGG would harm their pursuit of a new and autonomous profession for psychotherapists. The most fundamental and probably least explicit argument was the old controversy between social psychiatry and psychotherapy. The psychotherapists feared both the loss of their social status and their absolute control over their psychotherapeutic methods as well as over the selection of their clients. The wider use of their methods by new groups of professionals and patients would eventually level out the differences and lead to the erosion of their extraordinary and privileged position. In other words, many psychotherapists feared that the merger of the IMP and the RIAGG would result in the decline of "real" psychotherapy and their professional status. ${ }^{35}$ The opposition by the IMP was strong and to some extent effective. Whilst the IMP was incorporated in the RIAGG, psychotherapy was given a formal distinctive position within the organization as the organizational unit for psychotherapy, the OEP. The anxiety of psychotherapists proved largely unfounded. It was not the social psychiatric tradition that dominated within the new RIAGG but the psychotherapeutic tradition. The social psychiatric care approach, in which social psychiatric nurses visited and supported their chronic patients, was replaced by a far more therapeutic approach in which patients had to visit the RIAGG, where social psychiatric nurses treated them with psychotherapeutic methods. ${ }^{36}$ Likewise, psychotherapeutic methods became the first option for patients with less severe disorders. Next, the IMP standard of multidisciplinary teamwork became the RIAGG standard. As in the IMP, the psychotherapists (regardless of their specific preparatory training) were almost as important as the psychiatrists themselves. Psychotherapeutic treatment became the gold standard and psychotherapists were the "élite force" of the RIAGG. Psychotherapists gained another victory when they were recognized as a profession in 1986. At the same time, the apprehension of psychotherapists was not completely unfounded: in the third section we will show that the victory of psychotherapy was only short-lived. In the 1990s the medically-oriented psychiatrists once more took over power and person-oriented classical psychotherapeutic methods became more peripheral.

\section{The Professionalization of the Psychotherapist}

In 1986 the Dutch government formally recognized the profession of psychotherapist as a distinct entity under the law. The Netherlands was the only country in the Western world to do this. Recognition of the profession implied amongst other things a well-described domain, a specific and formally recognized education programme and a title reserved only

\footnotetext{
${ }^{35}$ Ibid., p. 27.

${ }^{36}$ Hilde Bakker, Leonie de Goei and Joost Vijselaar, Thuis opgenomen. Uit de geschiedenis van de sociale psychiatrie in Nederland, Utrecht, $\mathrm{NcGv}, 1994$, pp. 125-31. See also Joop van Londen,
}

Opkomst en neergang van de sociale psychiatrie;

kan het boek van de sociale psychiatrie al worden gesloten en terzijde gelegd?, Utrecht, Trimbos-instituut, 2001. 


\section{Psychotherapy in The Netherlands after the Second World War}

for those who were officially registered as psychotherapists. It is therefore fair to describe the history of Dutch psychotherapy up until 1986 as the evolution of the profession itself.

The creation of a separate profession can be analysed by using sociological concepts stemming from the literature on professionalization. Dominant in the traditional sociological literature is the view that the professionalization of a certain group always follows more or less clear-cut historical steps. ${ }^{37}$ According to Hans Reijzer, who wrote the history of the professionalization of psychotherapy in the Netherlands: "Psychotherapists have had to be fitted, in terms of organization, into existing structures; funding and remuneration have had to be settled, training established and recognition won", and subsequently "the profession is also subject to forces from outside such as welfare and the financial circumstances of the state". ${ }^{38}$ In this section we will describe the formation of the psychotherapist from this perspective, and reconstruct this history of professionalization by describing two major processes: the differentiation from other disciplines, and the creation of homogeneity among psychotherapists. A third process, the organization of funding in order to make psychotherapeutic treatment accessible for all patients, will not be described here. ${ }^{39}$

\section{The Process of Differentiation}

From the perspective of professionalization theory, the formation of a professional society is often considered the starting point for the creation of a distinct profession. ${ }^{40}$ The Dutch Society of Psychotherapy (NVP) was established in 1930. The society admitted psychiatrists as ordinary members and general doctors who practised psychotherapy as extraordinary members. However, this was not yet a move towards a distinct profession; it was mainly a defensive action to prevent a growing number of laymen from becoming therapists, the further fusion between psychoanalysis and psychotherapy and the monopolizing of psychotherapy by psychoanalysts.

The foundation of the NVP was part of a broader European development, with the German Allgemeine Ärztliche Gesellschaft für Psychotherapie (Association of Medical Psychotherapists) as its nerve centre. Established in 1928, this Association had among its members foreign psychotherapists from Austria, Switzerland and the Netherlands. ${ }^{41}$ The problems psychotherapists had to face in these countries had much in common, including that of the medical status of psychotherapy and its relation to psychiatry and psychoanalysis. Subsequently, there were the difficulties of social recognition, and of setting the boundaries for the psychotherapeutic domain in two areas: the kind of human problems that can be

\footnotetext{
${ }^{37}$ See, for example, Andrew Abbott, The system of professions: an essay of the division of expert labor, University of Chicago Press, 1988, on p. 10.

${ }^{38}$ Hans Reijzer, Naar een nieuw beroep. Psychotherapeut in Nederland, Houten, Bohn Stafleu Van Loghum 1993. Reijzers' thesis, was strongly influenced by the formal recognition of the profession by law in 1986, which he interpreted as a more or less final phase in the process of professionalization. This perspective gives his work probably some features of "Whig history", and offers also evidence for Abbott's thesis that professionalization is not
}

one-dimensional but an ongoing process. The perspective of professionalization can be used for heuristic purposes, not as an finalistic theory, see Abbott, op. cit., note 37 above, pp. 3-31.

${ }^{39}$ This highly complex history is described in detail by Oosterhuis, op. cit., note 4 above, and Reijzer, op. cit., note 38 above, on pp. 168, 200-11.

${ }^{40}$ Giel Hutschemaekers and Laura Neijmeijer, Beroepen in beweging. Professionalisering en grenzen van een multidisciplinaire GGZ, Houten, Bohn Stafleu van Loghum, 1998, on pp. 59-63.

${ }^{41}$ Reijzer, op. cit., note 38 above, pp. 23-7. 


\section{Giel J M Hutschemaekers and Harry Oosterhuis}

treated by psychotherapy; and the definition of what constitutes a psychotherapeutic relationship or intervention.

Even though the first to join the NVP were almost all members of the Psychoanalytic Society, from the beginning the NVP kept its distance from psychoanalysis. This could be viewed as one of the first steps towards the professionalization of psychotherapists. ${ }^{42}$ The distinction made between psychotherapy in general and psychoanalysis in particular was both ideological and pragmatic. In the ideological sense the NVP was more liberal than the Psychoanalytic Society: it did not agree with the claim of psychoanalysis that all physical, and mental and neurotic complaints were symptoms of underlying psychogenic conflicts, and that the only psychotherapeutic method was that of the couch. In the pragmatic sense, the divergence was based more on economics: in order to get formal recognition and obtain financial resources it was necessary to broaden the appeal of psychotherapy and make it accessible for people in less privileged social classes. The stand off from psychoanalysis enabled the gap between mainstream psychiatry and psychotherapy to be bridged. This was strengthened by the exclusion of laymen from the NVP. ${ }^{43}$

The distance that the new Psychotherapeutic Society placed between it and classical psychoanalysis had direct consequences for the social acceptance of psychotherapy as a whole. The Catholic and orthodox Protestant churches, whose influence in this denominational segregated society was far reaching, vigorously condemned classical psychoanalysis. ${ }^{44}$ Catholics and orthodox Protestants were strongly opposed to finding sexual causes of neurotic distress. Therefore, the broadening of the concept of psychotherapy enabled them to show more respect towards it and integrate this form of treatment into the existing Catholic and Protestant institutions for mental health care. For example, the Protestant psychiatrist, S J P Dercksen was able to set up a department for psychotherapy within the Protestant mental health foundation in Amsterdam in $1950 .{ }^{45}$ The Catholic effort was less successful and never resulted in a Catholic institution for psychotherapy. At the same time, some Catholic psychiatrists used the broadening of the concept to develop their own forms of psychotherapy. This is illustrated by the work of the Catholic psychiatrist A Terruwe. She was very explicit in her rejection of some psychoanalytic concepts, but at the same time she wrote to the National Health Board in 1949 that: "psychotherapeutic treatment is extremely good for many people, and may be very helpful for a better family-life" ${ }^{46}$ For her, neurosis was not only a sexual problem, but a disturbance in the relationship between man and God. H C Rümke, a very influential Protestant professor in psychiatry at the University of Utrecht and an advocate of psychotherapy, stated that atheism had to be interpreted as a neurotic state.

After the Second World War, another distinction surfaced: the differentiation between psychotherapists and psychiatrists. This process started very slowly; at first it seemed that the NVP was doing exactly the opposite, trying to tighten the relation between psychiatry and psychotherapy. On various occasions the Society asked for recognition from the Dutch Society of Psychiatry and Neurology (NVvPN; from 1972, NVvP). The recognition of psychotherapy as a specific treatment was necessary in order to obtain professional training

\footnotetext{
${ }^{42}$ Ibid., p. 36.

${ }^{43}$ See Oosterhuis, op. cit., note 4 above.

${ }^{44}$ Ibid., pp. $40-1$.
}

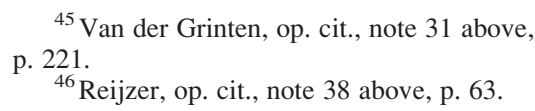




\section{Psychotherapy in The Netherlands after the Second World War}

in psychotherapy and also to receive payment by Medicaid. But each time the request was made the NVvPN remained aloof, stating that there was no role for the NVP in the field of psychiatric work. Paradoxically, these repeated efforts to marginalize the Society led to all kinds of actions by psychotherapists and thus promoted the emancipation of psychotherapy. Psychotherapists tried to influence official institutions in order to receive both payment and formal recognition. Their endeavours were successful. In 1950 a commission led by the Minister of Social Affairs recognized the positive effects of psychotherapeutic treatment and recommended the introduction of psychotherapy to Medicaid. ${ }^{47}$ In 1953 the National Health Council agreed to finance some psychotherapy, but this did not occur until 1959 and then only for psychotherapy by resident psychiatrists. ${ }^{48}$

A further step in the process of differentiation between psychiatry and psychotherapy was achieved by the introduction of new psychological insights and methods, as a result of lectures given by psychologists. The first guests, F J J Buytendijk and D J Van Lennep, both professors of psychology at the University of Utrecht and representatives of the phenomenological tradition, were invited in the early 1950s. Later psychologists introduced new methods to the NVP, such as the Rogerian approach. In the early 1960s psychologists became permanent guests at the meetings of the Society. Jos H Dijkhuis, Professor in Clinical Psychology at the University of Utrecht and Director of the Medical Institute for Psychotherapy in Utrecht, was in 1961 the first person to receive a permanent invitation. Finally, in 1966, the Society opened its doors to psychologists. Psychotherapy was no longer reserved only for psychiatrists: this was probably a decisive step towards making psychotherapy into a separate profession. Thus the increase in cultural awareness of psychologymore self-understanding and self-reflection in a psychological sense-also affected psychotherapists and they too became less medical and increasingly psychological.

The process of differentiation did not end the divisions between psychiatrists and psychotherapists. The inclusion of psychologists in the Society of Psychotherapy led to a new process of differentiation, i.e. between psychologists and psychotherapists. In 1961, five years before the NVP admitted psychologists as members, the Netherlands Institute for Practising Psychologists (NIPP, later NIP) set up a commission for psychotherapy. The Chairman was Jan Dijkhuis—brother of Jos H Dijkhuis-who was Professor of Clinical Psychology at Leiden and a pioneer in the new Rogerian therapy. According to this commission, a distinction should be made between psychological help and psychotherapy. Whereas psychological help was learned at the university, psychotherapy was not. Therefore, psychotherapy had to be regarded as a postdoctoral specialization for psychologists working in mental health. The committee recommended establishing postdoctoral studies and a register for psychotherapists. However, the Board of the NIP was reluctant to comply with these recommendations as they thought that recognition of the specialization would imply the toleration of a differentiation within the field of psychology. At the time no decision was made, with the result that those psychologists who wanted to become psychotherapists left the NIP. As stated above, from 1966 onwards they were entitled to become members of the NVP. Psychotherapy remained a stepchild of the NIP for a long time. For those psychologists working in clinical practice, post-academic training was established. With this, the psychologists in the NIP seemed to validate the difference between

${ }^{47}$ Ibid., p. 64.

${ }^{48}$ Ibid., pp. $65-67$. 


\section{Giel J M Hutschemaekers and Harry Oosterhuis}

themselves and the psychotherapists. It was only in 1989 that a direct connection was achieved between the register of clinical psychologists and psychotherapists.

The creation of the profession of psychotherapists led to a differentiation between psychiatrists-psychotherapists and psychiatrists non-psychotherapists. The same distinction occurred within the profession of psychologist. In the early 1970s, the widening of basic studies for psychotherapy developed further by opening the NVP to academics from outside the psychiatric and psychological disciplines. In 1970 other academics such as andrologists, educationists, sociologists and general doctors gained the right to become members of the NVP. In addition, in 1972 even non-academics such as social workers with advanced studies were allowed to join. ${ }^{49}$

With this process of differentiation, the field of psychotherapy took on a new meaning. Whilst in 1930 it was a medical treatment directed towards internal psychic trauma, the arrival of the psychologists meant that psychotherapy gained a more "psychic" dimension, visible with the appearance of new methods such as behavioural therapy and the clientcentred approach. In the 1970s psychotherapy once more extended its domain and methods: social workers brought a new vision focused on the group and especially the family unit and even extended to society as a whole. Their idea was that psychotherapy "must be a form of social action". ${ }^{50}$ At the same time, however, psychotherapy became ever more sophisticated, reserved for those specialists who received a lengthy training for the job and who were members of the psychotherapeutic society. Laymen who offered psychotherapy were accused of charlatanism. Psychotherapy began to look more and more like "interventions carried out by official psychotherapists". 51

\section{Creating Homogeneity}

Before the 1960s psychotherapy was still reserved for psychiatrists. The NVP brought together those psychiatrists who were interested in psychotherapy and organized conferences, lectures, workshops and training for them. From the outset, vocational training was a central aim of the Society. It was a way of deepening the knowledge and practice of psychotherapy, but also of creating more homogeneity.

After the Second World War, the NVP tried to extend its training activities to all psychiatrists. In a 1947 report on training, the NVP demanded more training for all medical students: general psychology should be made a required subsidiary subject in the study of medicine at the first level, and psychoanalytic psychology in combination with psychopathology at the second level. For doctors specializing in psychiatry, the Society demanded training in psychotherapy and for psychiatrists with a differentiation for psychotherapy, a formal postgraduate training. ${ }^{52}$

The NVP however never became the central organization for training in psychotherapy. In the 1950s the first teaching of psychotherapy took place in the universities; more specialized training was given in the workplace by experienced psychotherapists. The

\footnotetext{
${ }^{49}$ Ibid., pp. 110-31.

${ }^{50}$ Ibid., p. 112.

${ }^{51}$ Commissie Verhagen, Eindrapport

van de werkgroep psychotherapie,
}

Leidschendam, Ministerie von Volkgesondheid en Milieu, 1980.

${ }^{52}$ Reijzer, op. cit., note 38 above, p. 53. 


\section{Psychotherapy in The Netherlands after the Second World War}

majority of these trainers were also members of the Psychoanalytic Society and most of them were members of the NVP as well. Later, with the emergence of new psychotherapeutic schools, new psychotherapeutic societies, such as the Vereniging voor Rogeriaanse therapie (VRT, the Society for Rogerian Psychotherapy) and the Vereniging voor Gedragstherapie (VGT, the Society for Behaviourial Psychotherapy) also developed their own training facilities. Parallel to this broadening of the NVP membership to psychologists, psychotherapeutic training became an element of the study of psychology. In the 1960s the vocational training in the psychotherapeutic institutes (IMP) was extended to general training in psychopathology and basic psychotherapeutic interventions. Thus a heterogeneous training system with different suppliers developed.

This mixture of training programmes did not lead to more heterogeneity among psychotherapists. On the contrary, in the years around 1970, the NVP made a virtue of the need for some coherence. It achieved homogeneity by constructing a new nomenclature. First the NVP "invented" a distinction between psychotherapeutic societies: the NVP claimed to be the general society of psychotherapy whereas the other societies that were related to therapeutic schools became specialized societies. ${ }^{53}$ Subsequently it created a sophisticated system of grades in training: students needed a preliminary training in general psychotherapy followed by a more specialized training in a specific therapeutic school. Only the combination of training elements led to registration as a psychotherapist by the NVP. In this way, the NVP turned the psychotherapist into a professional with general knowledge in different psychotherapeutic approaches and specialist knowledge in one or two specific areas. In 1973 a general examination framework was set up by the society. ${ }^{54}$ Therefore, instead of being an organizer of training programmes, the NVP became the agency that formally recognized the differing programmes, and, in a word, it supervised them.

This general training, followed by specialized training, suggested equality between the various psychotherapeutic traditions and harmony and peaceful "cohabitation" of all kinds of psychotherapeutic paradigms. But appearances can be deceptive. Not all psychotherapeutic traditions were accepted as elements in the training programmes. In fact, some psychotherapeutic traditions were never recognized by the Society, the most striking example being that of Gestalt psychotherapy. According to Reijzer, the psychoanalysts within the Society had all kinds of problems with Gestalt psychotherapy and Gestalt psychotherapists, and because they formed a majority they were able in 1974 to exclude this psychotherapeutic tradition from the society. ${ }^{55}$ Thus the Society's training programme also led to more homogeneity by excluding some forms of psychotherapy.

In the early 1970s the majority of psychotherapists were also still registered as psychiatrists, but the group of psychotherapist-psychologists was thriving. As early as 1961, the NVP speculated on the possibilities of starting a curriculum for psychotherapy at the university. In 1971 these plans became more concrete with the nomination of A van Dantzig as Professor of Psychotherapy in the medical department at the University of Amsterdam. Together with his colleague J Barendregt, Professor of Psychology, he launched plans for a new academic discipline in psychotherapy. In 1974 these plans led to the establishment of an interdisciplinary study committee. Two years later the Board of the University set up a

\footnotetext{
${ }^{53}$ Ibid., p. 111.

${ }^{54}$ Ibid., p. 126-7.
}

${ }^{55}$ Ibid., pp. 157-61. 


\section{Giel J M Hutschemaekers and Harry Oosterhuis}

programme committee. However, a new curriculum never came to fruition; in 1977 the department of psychology broke with the committee. ${ }^{56}$ According to van Dantzig, this was due to the psychologists' fear of waning popularity for their own study: with an interdisciplinary doctoral programme, students would have had the opportunity to leave psychology for psychotherapy. ${ }^{57}$ In the 1980 s the rift between university and vocational training became even more evident with the emergence of the RINOs (Regional Institute for Schooling and Retraining in Mental Health Care). The RINOs became responsible for the training of psychologist-psychotherapists, while psychiatrists kept their own training as part of their regular medical education. ${ }^{58}$

The NVP slowly moved from being a scientific society to a professional society with all the characteristics of a trade union. This change was marked by the shift from organizing its own schooling programmes, to the setting up of a grading system for the various training programmes. ${ }^{59}$ Future moves also attested this shift: the NVP tried to underpin the financial position of psychotherapists by asking the National Medicaid Council for formal recognition of psychotherapy and by proposing psychotherapy as a regular treatment in mental health contexts. These attempts led to better societal recognition of psychotherapy, resulting in 1986 in a formal recognition of the profession of psychotherapist by law, the so-called "phénomène hollandais". 60

\section{Recognition of the Profession of Psychotherapist}

As early as 1973 the first step towards a separate and distinct profession for psychotherapists was taken, with the recommendation of the state commission of De Vreeze concerning the law on the regulation of work and workers in health care. Under the previous 1865 law, the practice of health care was restricted to medical doctors. However, in the workplace all kinds of professionals practised health care. The Dutch Medical Society did not want to give up its privilege. De Vreeze found a way out by proposing a new law in which health professions across the board received formal recognition whilst, at the same time, all medical treatment was restricted to medical doctors. In the appendix to the proposal a special section was reserved for psychotherapy. The commission advised formal recognition of the profession of psychotherapy. This met with much opposition; the society of psychiatrists and the society of psychologists were strongly against it. Both denied the existence of psychotherapy as a distinct profession.

In 1977 the National Inspectorate for Mental Health Care took a second step in the move towards a distinct profession for psychotherapists by setting up the Broad Commission for Psychotherapy (commission Verhagen). The commission's purpose was to study the various existing views on psychotherapy. In 1978 it published a discussion paper and in 1980 its final report. ${ }^{61}$ Central to this was the statement that psychotherapy was a distinct discipline, meaning that the profession of psychotherapists needed formal recognition. The commission also stated that psychiatrists were by definition also psychotherapists. Verhagen also

\footnotetext{
${ }^{56}$ Wim de Waal, Geschiedenis van de psychotherapie in Nederland, Den Bosch, De Nijvere Haas, 1992, on pp. 99-104.

${ }^{57}$ Ibid., p. 103.

${ }^{58}$ Hutschemaekers and Neijmeijer, op. cit., note 40 above, p. 50.
}

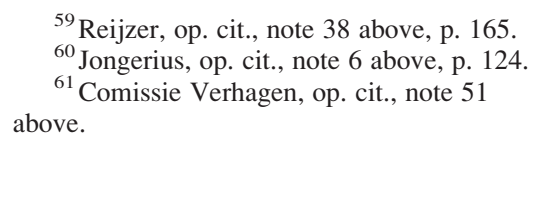




\section{Psychotherapy in The Netherlands after the Second World War}

gave advice on the training of psychotherapists and said that an academic qualification was a necessary requirement for psychotherapeutic training and registration. This led to the exclusion of social workers. Subsequently training was divided into two phases: an initial phase leading to formal registration as a psychotherapist, and a specialist phase developed and organized by the various specialist societies. The report's recommendations led in 1986 to the formal recognition of psychotherapy as a distinct profession under a temporary law. Finally, in 1993, psychotherapists gained a rightful place under the new law known as Wet BIG or the Individual Health Care Professionals Act.

\section{Recent Developments}

In the late 1980s the position of psychotherapy and psychotherapists seemed unassailable. Psychotherapists were formally recognized and the psychotherapeutic tradition dominated the RIAGG. So far, the data available from that period show a further increase in the influence of psychotherapy. The number of registered psychotherapists rose from 3,738 in 1991 to 5,138 in 1999 , demonstrating that psychotherapy was flourishing. ${ }^{62}$

However, as already noted, appearances can be deceptive. There are several indications that the traditional forms of psychotherapy as well as psychotherapists themselves are in trouble. Firstly, over the last few years a large number of psychotherapists have left the RIAGG in order to establish their own private practices. Secondly, following a period of a surplus of psychiatrists, ${ }^{63}$ the last few years has shown a shortage of these professionals, ${ }^{64}$ whereas at the same time no one seems to be worried about the shortage of psychotherapists in the RIAGG. Thirdly, psycho-pharmacological therapies have made their comeback within the RIAGG. Finally, it is not clear whether the profession of psychotherapists will retain its autonomy. In this last section, recent trends will be discussed and some hypotheses about what is going on will be formulated.

\section{The Practice of Psychotherapy}

The RIAGG was in a numeric sense an enormous success. When it opened in 1982 only seven out of 1,000 inhabitants asked for help. In 1988 this number had doubled to fourteen out of 1,000 and in 1996 had risen to almost seventeen persons per 1,000. Even if the interpretation of these figures is complex, it is generally accepted that a proportion of this increase was due to the lowering of the barriers for patients to get help. Mental health care had therefore become more accessible for more patients. ${ }^{65}$ This rise in the numbers receiving help produced several results. The first was an increase in the workload of

\footnotetext{
${ }^{62}$ Giel Hutschemaekers, Kalinka van der Camp, Marion van Hattum, Psychotherapie in getallen, Utrecht, Trimbos-instituut, 2001, on pp. 30, 41. The figures include about 1,500 psychiatrists. Exact numbers of clients in psychotherapy are missing. But the total number of ambulatory clients seeing a psychiatrist or a psychotherapist in 1999 was 244,300 , over 50 per cent of the total number of ambulatory clients in mental health care.
}

\footnotetext{
${ }^{63}$ Paul Schnabel, De psychiater in beeld, Utrecht, NcGv, 1982, pp. 33-49.

${ }^{64}$ Giel Hutschemaekers, 'Hoe meer psychiaters, des te groter het tekort? De psychiater en de arbeidsmarkt', Maandblad Geestelijke volksgezondheid, 1993, 48: 1171-86, p. 1175.

${ }^{65}$ Giel Hutschemaekers, 'Wordt Nederland steeds zieker? Kengetallen en achtergrondanalyses', Maandblad Geestelijke Volksgezondheid, 2000, 55: 314-35.
} 


\section{Giel J M Hutschemaekers and Harry Oosterhuis}

psychotherapists. The old multidisciplinary approach was criticized and became one of the symbols of the unpopular bureaucracy of the RIAGG. It led also to the development of more and new pragmatic therapeutic methods such as "short-term psychotherapy" 66 . These techniques were quite controversial, particularly for those psychotherapists who specialized in the classical dynamic psychotherapies and who were obliged to work with these new methods. These techniques were also controversial because they led to serious questions concerning the essence of psychotherapy. ${ }^{67}$

In the late 1980s a second result of the popularity of psychotherapy was a further decrease in social psychiatric methods for the care of chronic patients because social psychiatric nurses tended to move away from work with chronic non-treatable patients, who received less help as a direct consequence. ${ }^{68}$ This was especially the case for those patients who were either not able or not motivated to visit the RIAGG. In the same period, the psychiatric hospitals emptied their long-stay departments by reducing admissions of chronic patients, many of whom were returned to society. The RIAGG was unable to give these patients the help they needed, and, as a consequence, the psychiatric hospitals had to organize their own ambulatory care. It was therefore less evident which organization was responsible for chronic patients on the street. On the one hand, this led to growing criticism of the organization of mental health care and on the other, to attempts to bring about a merger between the psychiatric hospitals and the RIAGGs.

Alongside this development in the RIAGG, a profound transformation took place within psychiatry. The socio-psychotherapeutic model of the 1970s lost many of its followers in favour of the bio-medical model. One typical aspect of which was the belief that psychic problems could be regarded as discrete entities, for example, diseases or disorders and not as dynamic deviations from the norm or maladaptive solutions to complex situations. The new paradigm enabled these disorders to be counted, their onset and course to be studied, and their organic causes investigated. With this renewed attention on biological factors, pharmacological treatment also gained in interest. The introduction of a new generation of antidepressants (SSRI) stimulated this evolution. The effects of Prozac, the most popular brand name, were hyped by the popular media. ${ }^{69}$

The shift towards the medical perspective had direct consequences for psychiatrists. The Psychiatric Society had long claimed that diagnostic research and the prescription of medication were the prerogatives of psychiatrists. Therefore, the formal position of psychiatrists within mental health care changed greatly as a result. However, this probably had the most dramatic consequences for the RIAGG, where psychiatrists were just members of a multidisciplinary team. With the emergence of biological psychiatry many psychiatrists were able to improve their position. This was further anchored with the merger between the RIAGGs and the psychiatric hospitals, because in the hospitals psychiatrists already held a much more secure position.

\footnotetext{
${ }^{66}$ See Paul Rijnders, et al., Kortdurend behandelen in de GGZ, Houten, Bohn Stafleu van Loghum, 1999.

${ }^{67}$ Jos H Dijkhuis, 'Psychotherapie een vak voor veel beroepen', Maandblad Geestelijke Volksgezondheid, 1989, 44: 1051-64.

${ }^{68}$ Bakker, et al., op. cit., note 36 above, pp. 23-9.
}

\footnotetext{
${ }^{69}$ See, for example, Emma Brunt, De breinstorm, Amsterdam, Arbeiderspers, 1994. See also T Pieters, M te Hennepe and M de Lange, Pillen \& psyche: culturele eb-en vloedbewegingen. Medicamenteus ingrijpen in de psyche, The Hague, Rathenau Instituut, 2002.
} 


\section{Psychotherapy in The Netherlands after the Second World War}

The reaction of psychotherapists to these transformations was defensive. As it became clear that their influence in the RIAGGs was rapidly declining, many withdrew into their consulting rooms, whilst others left the organization and started private practice. The use of psychotherapeutic interventions by social psychiatric nurses and general psychologists increased the damaging effect on psychotherapists, who lost both their special position and their privileged status. Within the space of a few years psychotherapists had lost much of their influence within the RIAGG. It was hardly surprising that, as a result, almost all the independent organizational RIAGG units for psychotherapy were abolished.

A consequence of this change was that in the institutions a pragmatic model of psychotherapy became dominant, practised mainly by social psychiatric nurses and psychologists. This psychotherapy was characterized by the small number of frequent sessions for less educated clients who had more severe problems and it was known as problem-oriented psychotherapy. In private practice the dominant model remained the traditional personoriented one. This therapy consisted of more intense sessions (more frequent, of longer duration, with more fundamental goals) for patients who were better educated and probably better integrated in society (as demonstrated by the number of private practice clients in paid jobs). In private practice, psychotherapists continued to use the psychodynamic, clientcentred frames of reference.

Until 1985 the private practice of psychologist-psychotherapists hardly existed, in contrast to that of the psychiatrist-psychotherapists. ${ }^{70}$ Of course, there were psychologistpsychotherapists who offered psychotherapy at home, but the number of their patients was negligible. After 1985 the situation changed dramatically. It is true that the increase was also due to a new finance system which enabled psychotherapy provided by nonmedical psychotherapists in private practice to be remunerated by Medicaid. ${ }^{71}$ However, the migration from the RIAGGs to private practice was much more than a financial and cosmetic operation. The psychotherapists themselves gave several explanations, but the feeling that predominated was that in the institutions they were losing their professional autonomy. They also complained about the bureaucratic system and the large arsenal of protocols and procedures. Other critics saw in the withdrawal of the psychotherapist a sign of a changing perspective on mental health care within the public mental health institutions. The revival of the bio-psychiatric model profoundly changed the main forms of treatment in mental health care within the institutions. In other words, the changing position of psychotherapists was not only a matter of power and status but also the result of a paradigm shift in mental health care. The introduction of new multidisciplinary guidelines that were "evidence-based" can be seen as an example of this shift. In the 2003 new multidisciplinary guidelines for depressive and anxiety disorders, all the traditional person-oriented treatments, such as psychoanalytic, client-centred and group psychotherapies, have been discarded due to lack of evidence concerning their effect.

\footnotetext{
${ }^{70}$ Schnabel, op. cit., note 63 above, on p. 58. Schnabel counted in 1980 more than 200 psychiatrists with a private practice (the total number of psychiatrists was 1,500). Ten years later, in 1990, Hutschemaekers counted 723 psychiatrists with a private practice (the total number was 1,598 ), in Giel Hutschemaekers, Hans van den Heuvel, Curd Jacobs, Beroep: psychiater. Een enquête onder
}

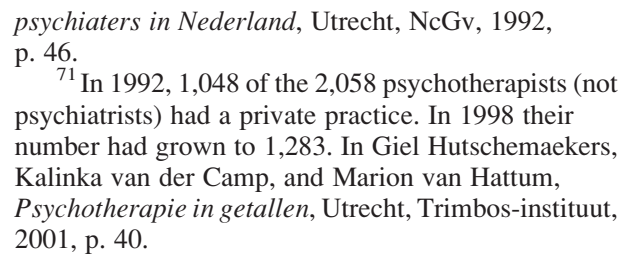
psychiatrists) had a private practice. In 1998 their number had grown to 1,283 . In Giel Hutschemaekers, Kalinka van der Camp, and Marion van Hattum, Psychotherapie in getallen, Utrecht, Trimbos-instituut, 2001, p. 40. 


\section{Giel J M Hutschemaekers and Harry Oosterhuis}

The End of the Psychotherapist?

In 1993 the Wet BIG was passed by parliament. With this law the position of psychotherapists seemed to be permanently formalized. However, five years later the situation had changed completely. In 1998 the government announced the closing down of the register for psychotherapists - the first step towards closing down the profession. So what exactly had happened in the intervening years?

The immediate reason for the renewed reflection on the position of the psychotherapist were studies on the various disciplines in mental health care. ${ }^{72}$ Figures revealed a huge overlap between the formal professions of so-called health care psychologists, psychotherapists and psychiatrists. ${ }^{73}$ Moreover, studies revealed that 90 per cent of clinical psychologists (psychologists who were registered with the society of psychologists, NIP) were also psychotherapists. ${ }^{74}$ The aim of the law, which was to increase clarity on the various professions in health care, had not been achieved.

The simplest solution to this confusion was to bring together clinical psychology and psychotherapy in one of two ways: categorizing the clinical psychologists under the psychotherapists, or the reverse, bringing the psychotherapists under the regime of the clinical psychologists. The Minister of Health Affairs preferred the second option. This was in line with almost all disciplines in mental health care. ${ }^{75}$ The unexpected decision resulted in the abolition of the legal status of psychotherapists and the reinforcement of clinical psychologists with no formal status.

There were several reasons for this choice. First, the logic of the law-the bill recognized a formal distinction between basic disciplines and specialities. The law treated psychotherapists as if they belonged to a basic discipline. However, in the field, psychotherapists were not seen at all as members of a basic discipline; they were treated as specialized psychologists and doctors. Clinical psychology on the other hand was seen by law and by professionals in the field as a specialty. Thus bringing psychotherapy under the regimen of clinical psychology was logical. The second reason had to do with the position of psychiatrists. They had never fully agreed with a separate discipline of psychotherapists. Until 1993 psychiatrists were allowed to use the title of psychotherapist. With the Wet BIG they lost this right despite their historical claim to the title and their formal training as psychotherapists. The announced closing down of the register for psychotherapists would solve their problem: the title of psychotherapist could again become available to them. From the professionalization point of view, the changing position of psychiatrists in mental health care was also likely to be influential. From the same perspective one could assume that psychologists too had their reasons for supporting the withdrawal of special or separate professional status from psychotherapists.

Probably the growing divergence between the academic world and psychotherapists was also responsible for this decision. Until 1990 research on psychotherapy was carried out by psychotherapists who worked in the departments of clinical psychology and psychiatry.

\footnotetext{
${ }^{72}$ Hutschemaekers and Neijmeijer, op. cit., note 40 above.

${ }^{73}$ Giel Hutschemaekers, 'Chaos in het beroepenveld', Maandblad Geestelijke Volksgezondheid, 1999, 54: 355-64.
}

\footnotetext{
${ }^{74}$ Marion van Hattum, Giel Hutschemaekers, De klinisch psycholoog gevolgd, Utrecht, Trimbosinstituut, 2001, p. 8.

${ }^{75}$ Minister of health, Beleidsvisie GGZ, The Hague, Ministerie VWS, 1998.
} 


\section{Psychotherapy in The Netherlands after the Second World War}

Over the last few years however, the number of psychotherapists working at universities has diminished, resulting in a growing distance between research on psychotherapy on the one hand, and the practice of psychotherapy on the other. In universities research became more and more focused on cognitive behavioural therapy (complaint-oriented), whereas psychotherapy in the field remained person- and problem-oriented. ${ }^{76}$ The result was that psychotherapy in the field lost its advocates in the academic world. Due to this shift, research on psychotherapeutic practice faded away. Psychotherapy lost its reputation of being "scientific".

\section{A Second Paradigm Shift?}

The Dutch Society of Psychotherapy (NVP) started as a defensive movement of doctors practising psychotherapy in the 1930s. Later it became more liberal and opened its doors to non-medical doctors, mainly psychologists. Over the last fifteen years it has once more become more defensive and initiated all kinds of conflicts on the essence of psychotherapy and the professionals who provide it. According to the NVP, the concept of psychotherapy should be limited to systematic activities performed by formally recognized psychotherapists. ${ }^{77}$ Interventions carried out by others have been excluded from that definition. The Society has apparently spent a lot of time defending the interests of its own members.

Recent developments in psychotherapy and the actions of the NVP can be interpreted as the classic pitfall of professionalization. They are perhaps also a good illustration of the "law of the retarding lead". From the historical view, however, it is too early to evaluate exactly what is happening. According to contemporary professionalization theory, psychotherapists themselves are unlikely to be entirely responsible for the current decline; the decline of psychotherapy and the end of the profession of psychotherapist is only partly due to the policy of the Society or the quarrels between the various disciplines. ${ }^{78}$ More fundamental changes in society probably account for the decline.

What kind of changes should we expect in the future? As in the 1960s, there is a shift in the way psychic problems are represented. ${ }^{79}$ Is this the end of an era of focusing on psychology? Probably not, for there are no signs that people are losing interest in the search for psychological explanations for their behaviour. It seems that we are facing the end of the dominance of the dynamic interpretation of problems. One hundred years ago Freud showed the world that behind overt intentions all kind of covert processes took place. This became the principal point of view among psychotherapists and spread to other disciplines and treatment methods in mental health care after the Second World War. It led to the decline of the distinction between social, psychic, and psychiatric problems. With the psychoanalytic frame of reference the idea came into being that every human problem was essentially a

\footnotetext{
${ }^{76}$ Cees van der Staak, H J Dalewijk, W Th A M Everaerd, 'Psychotherapie als specialisme',

Maandblad Geestelijke Volksgezondheid, 1999, 54: 390-7, p. 397.

${ }^{77}$ NVVP and NVP, 'Nadere definiëring psychotherapie', in Giel Hutschemaekers, Wim Brunenberg, Hans Spek, Beroep: psychotherapeut; een verkennend onderzoek naar persoon, werk en werkplek
}

van de psychotherapeut in Nederland, Utrecht, NcGv, 1993, pp. 93-4.

${ }^{78}$ Abbott, op. cit., note 37 above, pp. 30-1, 33.

${ }^{79}$ Serge Moscovici, La psychanalyse, son image et son public, Paris, PUF, 1971. Those shifts will often start within the scientific world and will diffuse subsequently in other circles of society. 


\section{Giel J M Hutschemaekers and Harry Oosterhuis}

psychodynamic problem and could be understood with psychodynamic insights and methods.

With the emergence of more pragmatic therapeutic methods and the renewed popularity of the medical model, we are entering a post-modern perspective on problems. Instead of one essential dynamic interpretation, different interpretations, related to different situations, are being constructed. The distinction between social, psychic, and psychiatric problems is reappearing. Best practices will be increasingly defined as depending on the setting in which the problem occurs and the success of earlier interventions. In health care this approach is called "stepped care". In social sciences the concept "contextual" is preferred. 